\title{
Erratum to : Effect of Endoplasmic Reticulum (ER) Stress Inhibitor Treatment during Parthenogenetic Activation on the Apoptosis and In Vitro Development of Parthenogenetic Porcine Embryos
}

\author{
Hye-Bin Park ${ }^{1}$, Mi-Jeong Kim², Bae-Dong Jung1, Seunghyung Lee², Choon-Keun Park², \\ Boo-Keun Yang ${ }^{2}$, and Hee-Tae Cheong ${ }^{1}$ \\ ${ }^{I}$ College of Veterinary Medicine and Institute of Veterinary Science, Kangwon National University, Chuncheon 24341, Korea \\ ${ }^{2}$ College of Animal Life Sciences, Kangwon National University, Chuncheon 24341, Korea
}

In the published article "Effect of endoplasmic reticulum (ER) stress inhibitor treatment during parthenogenetic activation on the apoptosis and in vitro development of parthenogenetic porcine embryos. Dev. Reprod. 2018; 22(3):235-244. https://doi.org/10.12717/DR.2018.22.3.235," the Fig. 1 was given incorrectly. The Editorial Office of Korean Society of Developmental Biology would like to correct the Fig.1. In addition, Fig. 1 had some mistakes and the corresponding authors asked change it with correcting one. The Editorial Office apologizes for any inconvenience that it may have caused.

The Fig. 1 should be corrected as follows:

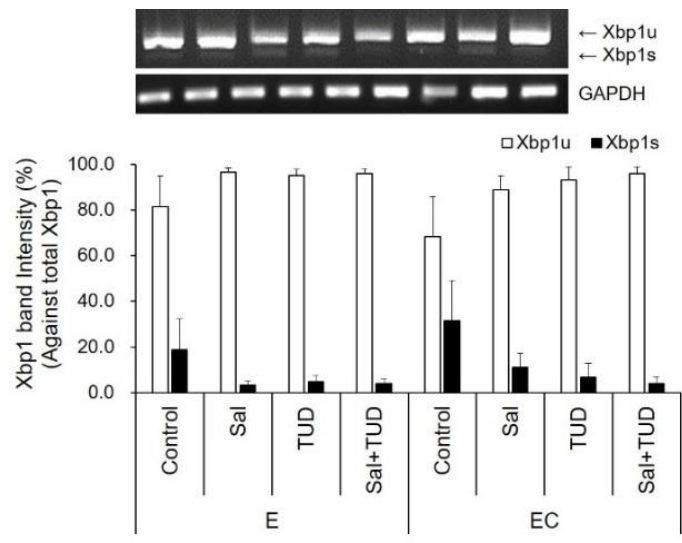

Fig. 1. Xbp1 mRNA expression in porcine parthenogenetic 1-cell embryos. The spliced and unspliced form of XBP1 mRNAs were detected by RT-PCR and band intensity was measured by a densitometer. Data are presented as means \pm SEM. E, electric stiulus; EC, E $+10 \mu \mathrm{M}$ Ca-ionophore (A23187) treatment; Sal, $200 \mathrm{nM}$ salubrinal; TUD, 100 $\mu \mathrm{M}$ TUDCA; Xbp1s, spliced XBP1; Xbp1u, unspliced XBP1.

\section{REFERRENCES}

Park HB, Kim MJ, Jung BD, Lee S, Park CK, Yang BK, Cheong HT (2018) Effect of endoplasmic reticulum (ER) stress inhibitor treatment during parthenogenetic activation on the apoptosis and in vitro development of parthenogenetic porcine embryos. Dev Reprod 22:235-244.

This is an Open Access article distributed under the terms of the Creative Commons Attribution Non-Commercial License (http:// creative-commons.org/licenses/by-nc/3.0) which permits unrestricted non-commercial use, distribution, and reproduction in any medium, provided the original work is properly cited. 